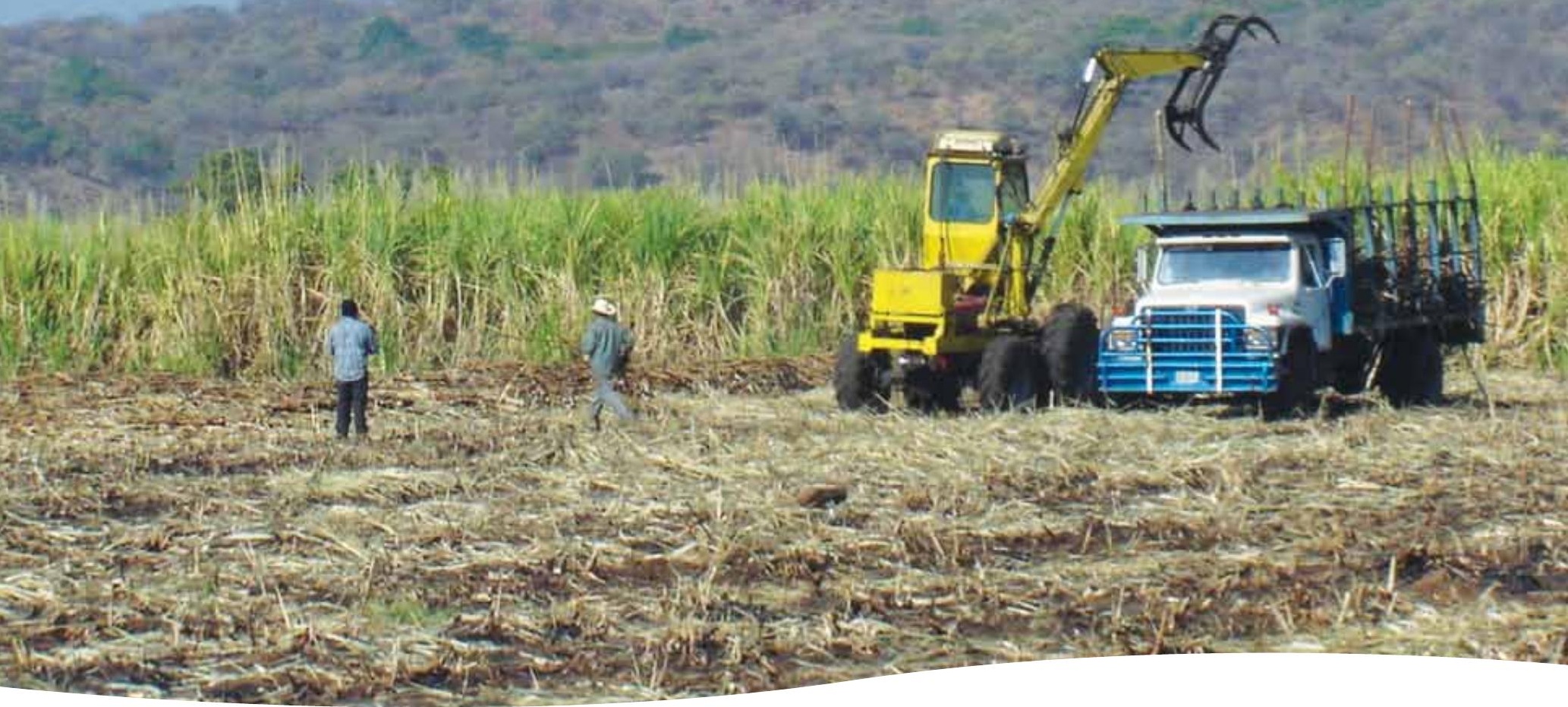

\title{
Legal and institutional frameworks at national and subnational levels for biofuel promotion in Mexico
}

Omar Romero-Hernández

Omar Masera

Sergio Romero

Miriam Grunstein

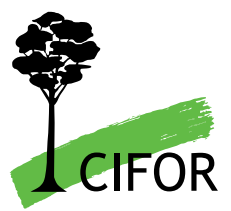





\section{Legal and institutional frameworks at national and subnational levels for biofuel promotion in Mexico}

Omar Romero-Hernández

Omar Masera

Sergio Romero

Miriam Grunstein 


\title{
Working Paper 63
}

(c) 2011 Center for International Forestry Research.

All rights reserved

Romero-Hernández, O., Masera, O., Romero, S. and Grunstein, M. 2011 Legal and institutional frameworks at national and subnational levels for biofuel promotion in Mexico. Working Paper 63. CIFOR, Bogor, Indonesia

Cover photo by Alfredo F. Fuentes Gutiérrex.

Place: Ingenio cañero Puruarán, Michoacán (Sugar cane factory in Puruarán, Michoacán.

Date: Abril 2009 (April 2009)

This report has been produced with the financial assistance of the European Union, under a project titled, 'Bioenergy, sustainability and trade-offs: Can we avoid deforestation while promoting bioenergy?' The objective of the project is to contribute to sustainable bioenergy development that benefits local people in developing countries, minimises negative impacts on local environments and rural livelihoods, and contributes to global climate change mitigation. The project will achieve this by producing and communicating policy relevant analyses that can inform government, corporate and civil society decision-making related to bioenergy development and its effects on forests and livelihoods. The project is managed by CIFOR and implemented in collaboration with the Council on Scientific and Industrial Research (South Africa), Joanneum Research (Austria), the Universidad Nacional Autónoma de México and the Stockholm Environment Institute. The views expressed herein can in no way be taken to reflect the official opinion of the European Union.

\author{
CIFOR \\ JI. CIFOR, Situ Gede \\ Bogor Barat 16115 \\ Indonesia \\ T $+62(251) 8622-622$ \\ $\mathrm{F}+62(251) 8622-100$ \\ Ecifor@cgiar.org
}

\section{www.cifor.cgiar.org}

Any views expressed in this publication are those of the authors. They do not necessarily represent the views of CIFOR, the authors' institutions or the financial sponsors of this publication. 


\section{Table of contents}

Acknowledgements

Abstract

vii

$\begin{array}{ll}\text { 1. Introduction } & 1\end{array}$

2. Regulatory and institutional framework for biofuel promotion in Mexico 2

2.1 The overall framework 2

2.2 The Constitution of Mexico $\quad 4$

2.3 Laws on the energy, environment and agriculture sectors 4

2.4 Bioenergy Promotion and Development Law 5

3. Policy framework for biofuel promotion in Mexico 11

$\begin{array}{lll}3.1 & \text { Level I policies } & 11\end{array}$

$\begin{array}{ll}3.2 & \text { Level II policies }\end{array}$

$\begin{array}{ll}3.3 & \text { Level III policies }\end{array}$

4. The Mexican framework in the context of biofuel laws and regulations in Latin America 18

$\begin{array}{lll}4.1 & \text { Purpose and objectives of the regulations } & 18\end{array}$

4.2 Implementing agencies $\quad 18$

4.3 Policy framework for promotion and development, and market promotion 19

4.4 Mandatory fuel requirements 19

4.5 Elaboration and enforcement of additional rules or standards 19

5. Discussion 21

5.1 Biofuels and food security $\quad 22$

5.2 Biofuels and energy security $\quad 22$

$\begin{array}{lr}\text { 6. Conclusions } & 24\end{array}$

$\begin{array}{ll}\text { 7. References } & 25\end{array}$

$\begin{array}{lr}\text { Appendix } 1 & 26\end{array}$ 


\section{List of tables, boxes and figures}

\section{Tables}

1 Ministerial roles under the Bioenergy Law

2 List of biodiesel feedstock projects

3 List of bioethanol feedstock projects

\section{Boxes}

1 Main Constitutional provisions related to energy and natural resources in Mexico

2 Mexican laws related to environment and energy

\section{Figures}

1 Mexico's legal framework in relation to bioenergy

2 A representation of Mexico's bioenergy-related policy framework

3 Map of areas targeted for cultivation of selected feedstocks for biofuels 


\section{List of abbreviations}

$\mathrm{C} 4$

$\mathrm{CNC}$

CONABIO

CONACYT

CONAFOR

CONANP

CRE

ECOSUR

EIA

FAO

FCPF

GMO

INIFAP

MXN

PEMEX

PROFEPA

R-PP

REDD

SAGARPA

SEMARNAT

SENER

UNFCCC
Consejo Consultivo de Cambio Climático

Confederación Nacional Campesina

Comisión Nacional para el Conocimiento y Uso de la Biodiversidad (National Commission for the Knowledge and Use of Biodiversity)

Consejo Nacional de Ciencia y Tecnología (National Council on Science and Technology)

Comisión Nacional Forestal (National Forestry Commission)

Comisión Nacional de Aéreas Naturales Protegidas (National Commission for Natural Protected Areas)

Comisión Reguladora de Energía (Energy Regulatory Commission)

El Colegio de la Frontera Sur

Environmental Impact Assessment

Food and Agriculture Organization of the United Nations

Forest Carbon Partnership Facility

Genetically modified organism

Instituto Nacional de Investigaciones Forestales, Agrícolas y Pecuarias (National Institute for Agriculture and Forestry Research)

Mexican peso

Petróleos Mexicanos, Mexico’s state-owned oil company

Procuraduría Federal de Protección al Ambiente (Federal Attorney for Environmental Protection)

Readiness Preparation Proposal

Reducing emissions from deforestation and forest degradation

Secretaría de Agricultura, Ganadería, Desarrollo Rural, Pesca y Alimentación (Ministry of Agriculture, Agriculture, Livestock, Rural Development, Fisheries and Food)

Secretaría de Medio Ambiente y Recursos Naturales (Ministry of Environment)

Secretaría de Energía (Ministry of Energy)

United Nations Framework Convention on Climate Change 


\section{Acknowledgements}

We would like to express our appreciation for the support provided by Universidad Nacional Autónoma de México (UNAM), Instituto Tecnológico Autónomo de México (ITAM), Asociación Mexicana de Cultura A.C., Red Mexicana de Bioenergía A.C. and Centro de Investigación y Docencia Económicas A.C. We would like to thank Manuela Prehn, Enrique Riegelhaupt, Caroline Taylor, Dominique Scalise and Andrea Romero-Hernandez for reviewing the document and providing useful comments and insights.

Furthermore, we would like to recognise support provided by the University of California, Berkeley, where part of this work was carried out. We also want to especially thank the Energy Biosciences Institute, the Center for Responsible Business of the Haas School of Business and the Laboratory for Manufacturing and Sustainability. 


\section{Abstract}

Mexico has recently taken significant steps towards promoting the bioenergy sector. Adoption of bioenergy is perceived as an opportunity to develop alternatives to fossil fuels, to foster economic development and to meet international commitments to reduce greenhouse gases. However, such opportunities are accompanied by concerns such as the effect of biofuel production on deforestation rates - concerns that may be addressed through policy instruments and proper program design. Therefore, this country report contains an analysis of the legal and institutional frameworks related to Mexico's bioenergy sector.

Practical experience with programmes and activities related to biofuels in Mexico is very limited. Therefore, the present report concentrates on analysing the provisions found in policies, laws and regulations, rather than on assessing project implementation and past practice. The report first examines the regulatory and institutional framework related to biofuel production and its use in Mexico, and then presents the policy framework for biofuel promotion in Mexico.

Mexico's legal framework is well defined. It is composed of three normative levels: the Constitution; statutory law issued by the federal and local legislatures; and administrative provisions that include regulations issued by the federal executive power and other rules created by administrative agencies, such as technical norms, directives and other sector-specific binding instruments. The policy framework is a top-down structure with national plans at the top; these are linked to several sector and ministerial plans, which are ultimately linked to specific programmes. These programmes include strategies and subprogrammes that need to be developed in order to target feedstock, production, trade and sustainability objectives such as: sustainable production of feedstocks for biofuel production; establishment of a national programme for biofuel research and technology development; design of system-product chains; investment plans; employment creation in rural areas; contribution to increased reconversion and productive diversification of the primary sectors; and contribution to the preservation of natural resources and biodiversity, thus reducing greenhouse gas emissions.

However, our analysis indicates that most of these programmes and plans are not mature. Only a few sets of laws specifically target biofuels, most of which are mainly directed towards the energy sector and ignore the potential impacts on deforestation. Even the most recently published programmes are, in effect, only a list of guidelines, structured under the logic of a business plan (vision, mission, objectives and actions). Mexico has documented lists of tasks and goals; however, documentation containing programme details or in-depth analyses of plans (beyond simple statements) is not fully available. In addition, there is need for long-term planning; for example, the Bioenergy Penetration Programme refers its strategic vision to the year 2012. Mexico is several steps behind other Latin American countries, particularly Brazil, regarding the establishment of a well-developed and stable biofuels market. Further efforts are required in the areas of agriculture and environment if the largescale development of biofuels is to be promoted in Mexico whilst avoiding deforestation and accruing a true mitigation of greenhouse gas emissions. Clear provisions and integrated mechanisms that foster the roles of the forestry and agriculture sectors in developing bioenergy whilst avoiding environmental damage have yet to be put into practice. 



\section{Introduction}

Biofuels are considered an important alternative to fossil fuels in meeting the growing global demand for energy sources. Factors driving the expansion of biofuels include higher oil prices, the need for costeffective and environment-friendly energy alternatives so as to create competitive economic conditions for local industry in many countries and the need to reduce greenhouse gas emissions (Segura 2008).

In this context, there is a pressing need to reinforce biofuel initiatives. Strong legal and institutional frameworks are required, in the fields of both energy and environment, to effectively foster the sustainable use of biofuels as an integral element of the energy mix of any country's economy.

Policy decisions by regional and national governments have served to promote biofuels in some regions, mainly in the United States, Brazil and the European Union (Charles et al. 2007). In addition, a number of laws, regulations and standards have come into force in these countries, covering issues ranging from biofuel production to economic incentives to support the development of the local industry. However, policy instruments in most other countries, particularly throughout Latin America, are still under development and do not cover all the essential aspects related to biofuel production, promotion and end-use.This report describes the main laws, regulations and policies related to biofuel production and use in Mexico. The report was prepared as part of Task 3.2 of CIFOR's project 'Bioenergy, sustainability and trade-offs: can we avoid deforestation while promoting bioenergy?'
The report first examines the regulatory and institutional framework related to biofuel production and use in Mexico, building on previous work in this area (Segura 2008, Masera et al. 2011). This framework is presented as a 3-level structure comprising the Constitution, statutory laws and regulations. The subsequent section presents the policy framework for biofuel promotion in Mexico from a top-down perspective, including the national development plan, interministerial initiatives, sector policies and specific bioenergy policies. This is followed by a general comparison of Mexico's frameworks with those of other Latin American countries, which serves as a base to identify voids and opportunities to boost the sustainable development of biofuels. A discussion on the divergence between stated regulations and policies and their implementation is provided in the final section, along with recommendations. A table containing the parameters and variables identified during the preparation of this working paper is provided in the appendix.

It should be noted that, as Mexico is only now beginning its activities in the liquid biofuels sector, practical experience on actual implementation programmes and activities is very limited. Therefore, the report concentrates on analysing the provisions found in policies, laws and regulations, rather than on assessing past practice. 


\section{Regulatory and institutional framework for biofuel promotion in Mexico}

\subsection{The overall framework}

Mexicos bioenergy legislation is new and has evolved in the complex context of the country's agricultural, environmental and energy policy. When the first pieces of legislation were crafted, in 2007, they mostly targeted the agricultural aspects of bioenergy. However, allegedly because agricultural organisations lobbied Congress, in particular the PRI (Institutional Revolution Party), the bill favoured mere agricultural production and disregarded conditions that would enable agriculture to become environmentally sustainable. Furthermore, the bill ignored issues related to consumption, regulating energy consumption only superficially.

That first bill to promote biofuels in Mexico came as a move to capitalise on the growing biofuels markets and turn some of Mexico's large sugarcane production into ethanol. The Mexican House and Senate passed the bill, but it was vetoed by the President because of its lack of scope concerning environmental and energy consumption sustainability.

Following a second round of congressional debate, a bioenergy bill was approved in February 2008. The new Bioenergy Promotion and Development Law (hereafter, the 'Bioenergy Law') defines ethanol and biodiesel fuels as produced from energy commodities or subproducts derived from agricultural activities. The law establishes basic principles to promote the production, distribution and sale of ethanolbased fuel and biodiesel and to facilitate technical and economic incentives for their development. The law charges the President with the direct obligation to promote the use of biofuels through the use of any available economic and international legal instruments, specifically mentioning the Clean Development Mechanism contained in the Kyoto Protocol to the United Nations Framework Convention on Climate Change (UNFCCC).
Subsequent to the Bioenergy Law, specific regulations and norms have evolved concerning the use of ethanol in gasoline and biodiesel in diesel fuel. Moreover, the law establishes basic requirements that private investors must meet in order to qualify for economic and technical incentives from the federal, state and municipal governments for infrastructure development.

It was expected that the new framework would open up substantial investment opportunities for biofuels markets in Mexico. However, such expectations have been thwarted by the government's inability to reverse policy measures such as diesel and gasoline subsidies, which are barriers to the growth of the country's bioenergy markets.

Therefore, for example, the expectation that a new legal framework could lead to the generation of carbon credits under the Kyoto Protocol to be sold to EU countries, where global warming and climate change legislation requires reduction of greenhouse gas emissions, has yet to be realised. Nevertheless, opportunity remains - that this dual revenue stream and the proximity to the US ethanol market may lead to a substantial biofuel industry in Mexico.

The Mexican legal framework is composed of 3 normative levels: the Constitution; statutory law issued by federal and local legislatures; and administrative provisions, which include regulations issued by the federal executive power proper and other rules created by administrative agencies such as technical norms, directives and other sector-specific binding instruments.

The Constitution of Mexico (Constitución Política de los Estados Unidos Mexicanos) forms the basis of the country's legal system. The Constitution establishes the overarching rules and principles pertaining to the structure of the Mexican federal government, and 
determines the competence and legal authority of the distinct branches of government within their specific jurisdictions. The Constitution also sets out the principles for the validity of laws made by government institutions; the salient principle is that all the acts and norms issued by such institutions must comply with the Constitution in order to be valid and enforceable. The statutory laws issued by federal Congress provide the legal fundamentals for activities while the administrative rules and regulations provide greater detail of laws' scope, limitations, and legal sanctions.

In this respect, as for other activities, the production and distribution of bioenergy fall under the jurisdiction of state and municipal authorities, and any related state or municipal laws and regulations must be aligned with the relevant federal law.
Mexico's legal framework in relation to bioenergy is depicted in Figure 1. The aim of this diagram is to facilitate understanding of the set of documents that have been issued by various departments of the Mexican government and that have a direct (but not necessarily exclusive) effect on the bioenergy sector. Note, however, that this is not an official representation. Furthermore, this set of legal documents is still under development, and it is expected that more laws and regulations will be issued and existing ones amended.

Currently, Mexico has only a few sets of laws specifically targeting biofuels. It is important to remember that most of these are related to the energy sector, although they also address environmental and agricultural matters. In particular, the Bioenergy Law defines the mode by which the biofuel industry is to

\section{Constitution}

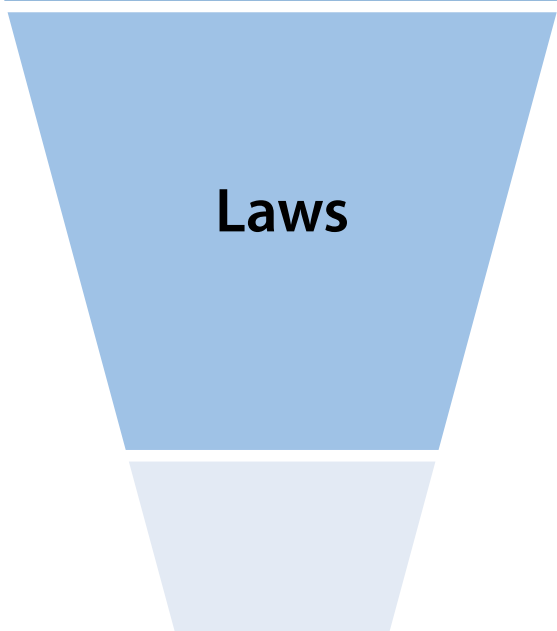

\section{Regulations}

Article 4. On the people's right to an adequate natural environment

Article 25. On the state's responsibility for national development

Article 27. On ownership and dominion over natural resources
1. Ecological Equilibrium and Environmental Protection Law
2. Rural Sustainable Development Law
3. Sustainable Forestry Development Law
4. Sustainable Use of Energy Law
5. Renewable Energy Use and Financing of Energy Transition Law
6. Bioenergy Promotion and Development Law 
evolve in Mexico as part of a broader policy aimed at achieving energy security, agricultural promotion and environmental sustainability.

\subsection{The Constitution of Mexico}

As stated above, all laws and regulations in Mexico must be aligned with principles in the Constitution. In this sense, Articles 4, 25 and 27 contain the main principles that determine the role of the Mexican state in matters concerning natural resources in general and the energy sector in particular (Segura 2008). A brief description of these legal provisions is presented in Box 1.

\subsection{Laws on the energy, environment and agriculture sectors}

A number of laws constitute the legal framework for the energy, environment and agriculture sectors. These laws define the role and scope of the Mexican state within each sector, by establishing the legal competence of each administrative department for the award of permits, regulatory oversight and even price determination for certain goods and services. They also serve as the governing framework with regard to biofuel promotion and the institutions responsible for related policies. Brief descriptions of the laws are provided in Box 2.

Participation in energy matters in Mexico is largely reserved for the state - for example, extraction and distribution of fossil fuels remain the sole

\section{Box 1. Main Constitutional provisions related to energy and natural resources in Mexico}

\section{Article 4: People's right to an adequate environment}

With respect to environment protection, the Constitution states in Article 4 that 'every individual has the right to an adequate environment for their development and wellbeing'. This precept has served as the basis for all laws and regulations related to sustainable development.

\section{Article 25: The role of the state in national development}

Article 25 defines the role of the state in performing economic activities, stating that '.... the state is empowered to govern national development to ensure it is all encompassing and sustainable; that it strengthens the sovereignty of the nation and its democratic regime; and that by way of promoting economic growth and employment, and a more fair distribution of income and wealth, it allows the full exercise of freedom and dignity of all individuals, groups and social classes'.

The article also stipulates that'... the state will plan, conduct, coordinate and orient national economic activity, and will undertake the regulation and promotion of the activities required by social welfare within the frame of the liberties set forth by this Constitution', and that '... the public, private and social sectors shall partake in national development with social responsibility, unimpaired by other economic activities which contribute to the nation's development'.

Similarly, this article establishes that the state'... will participate alone or jointly with the social and private sectors, in compliance with the law, to pursue and organise all development priority areas' and that'... the law will encourage and protect economic activities undertaken by the private sector, and will provide conditions such that the private sector's development contributes to national economic development'.

\section{Article 27: Ownership and title over natural resources}

Article 27 provides that '... the property of lands and waters located within the limits of the national territory belongs originally to the nation, which has the right to transfer its title to the private sector, thus establishing private property'.

It also states that '... the nation holds unabated property of all natural resources in the continental and insular shelf; ... mineral solid fuels, oil and all solid, liquid and gas hydrocarbons'.

Article 27 also sets out the limits and conditions for land property and dominion by foreigners. This article stipulates that 'only Mexican-born or naturalised citizens, as well as Mexican associations, have the right to acquire land, water and its accessions, or to obtain mines and water exploitation concessions. The state will grant the same right to foreigners, once they convene with the Secretariat of Foreign Affairs to be considered as national citizens with regard to the mentioned goods, and not to claim, for that reason, the protection of their respective governments on their behalf.' 
responsibility of the state and all operations must be carried out through Petróleos Mexicanos (PEMEX; Mexico's state-owned oil company) - and private investors face major restrictions in the energy sector. However, Mexican law is more permissive of private participation in the bioenergy industry. Under relevant laws, any citizen can produce up to 500 litres/day of biofuels; there is no need to obtain federal permits for production, storage, transport and management of ethanol and biodiesel produced at small scales, although larger volumes do require such permits. However, to date, there is no information on the operation of large-scale productions, as programmes are still under development and evaluation (see Section 3).

\subsection{Bioenergy Promotion and Development Law}

\subsubsection{Aims of the Bioenergy Law}

The purpose of the Bioenergy Promotion and Development Law (hereafter the 'Bioenergy Law') is to promote and develop bioenergy in order to contribute to energy diversification and sustainable development as conditions that benefit the Mexican agriculture sector.

This law was enacted following vigorous public policy discussion regarding the production and consumption of bioenergy in Mexico. In 2006, an initiative was presented by a congressional member of the Partido Revolucionario Institucional (PRI) - a party historically linked to rural unions such as the CNC (Confederación Nacional Campesina) and the sugarcane producers union. As such, the initiative had a marked rural bias, favouring the interests of these groups.

Following congressional discussion and approval, President Felipe Calderón vetoed the initiative on the grounds that it confused the issue of biofuel production with that of biofuel consumption; in effect, his criticism was of the absence of participation by energy authorities in the drafting of the initiative.

In his observations, President Calderón emphasised the need to include feedstocks other than corn and sugarcane, which were the dominant crops in the first initiative. He also pointed out the need to pay attention to the final stages of bioenergy use through regulation of distribution, marketing and consumption, as well as of production.

The Bioenergy Law, which came into operation in February 2008, is the first law in force for bioenergy promotion and development in Mexico. To achieve its goals of promoting and developing bioenergy, the law details overall objectives, specific activities and responsibilities of the implementing agencies in relation to programmes, policies and strategies to foster bioenergy production. It also establishes the basis for the development of market rules and criteria for the operation of the bioenergy market in Mexico.

Its specific aims are to:

- promote the production of inputs (feedstocks) for bioenergy from agricultural activities, forestry, algae and biotechnological and enzymatic processes in rural Mexico, without jeopardising the country's food security or sovereignty, pursuant to Articles 178 and 179 of the Rural Sustainable Development Law;

- develop the production, marketing and efficient use of biofuels to contribute to revitalising the rural sector, generating employment and improving quality of life, particularly in marginalised and very marginalised areas;

- promote, in terms of the Planning Law, regional development in disadvantaged rural communities;

- seek to reduce pollutants in the atmosphere and greenhouse gases, using international instruments contained in the treaties to which Mexico is a party; and

- coordinate activities amongst federal, state and municipal authorities.

\subsubsection{Coordinating body}

Most Mexican law and policy instruments establish coordinating and/or governing bodies to oversee activities undertaken by multiple agencies to achieve a common purpose or strategy. In this sense, the Bioenergy Law establishes a coordinating body, the Interministerial Commission on Bioenergy Development, to oversee all activities undertaken by various agencies (Appendix 1). This coordinating body, which is headed by the Minister of Energy, is composed of representatives from the Ministries of Environment, Agriculture, Economy and the Treasury. 


\section{Box 2. Mexican laws related to environment and energy}

\section{Law for the Use of Renewable Energy and Financing the Energy Transition of 2008}

The regulatory strategies and capacity of the Renewable Energy Law specifically target the use of renewable energy sources and clean technologies that generate electricity for purposes other than the public service of electric power. It also aims to establish a national strategy and the required instruments to finance energy transition in Mexico (Appendix 1).

This law grants the Energy Regulatory Commission (CRE) a wider set of legal powers, such as as the authority to award permits, enact norms and establish price-setting methodologies for electricity generation undertaken with renewable energy; and to establish regulations on land use and construction that take into account and benefit those owners or occupants of land that use renewable energy.

Under the law, following the land change approval, the construction and operation of any power-generation project with a capacity greater than $2.5 \mathrm{MW}$ must involve the participation of local communities and regional groups and potentially affected groups and individuals interested in monitoring projects. The purpose of these provisions is to reconcile sustainable rural development, environmental protection and land rights.

\section{Sustainable Use of Energy Law of 2008}

The purpose of the Sustainable Use of Energy Law is to promote the sustainable use of energy through ensuring optimal use during processes and activities related to energy, from its generation to consumption, including cogeneration.

The law provides for the design of a National Programme for the Sustainable Use of Energy. This programme, a topdown federal plan, includes strategies, objectives, actions and targets oriented towards:

- providing goods and services for federal agencies that ensure the best available energy efficiency practices;

- developing and implementing ongoing programmes through federal agencies for the sustainable use of energy in government real property and movable goods, and applying criteria for the sustainable use of energy in the acquisition, leasing, hire works and services undertaken by federal agencies;

- promoting scientific and technological research on sustainable use of energy;

- including topics on sustainable use of energy in elementary, junior high and high school curricula;

- promoting, at a senior level, the training of specialists in sustainable use of energy;

- promoting the application of technologies and the use of computers, energy-efficient appliances and vehicles;

- establishing a standards programme for energy efficiency;

- ensuring that the population has effective and accurate information on energy consumption, equipment, appliances and vehicles that require electric power for operation;

- establishing a strategy for the modernisation of public transportation and the implementation of electric transportation systems for commuter routes (with such routes having indicative annual targets to reverse the trend of consumer use of hydrocarbon-fuelled transport); and

- developing a strategy for replacing incandescent lamps with energy-saving fluorescent lamps.

\section{Sustainable Forestry Development Law of 2003}

The purpose of the Sustainable Forestry Development Law is to regulate and promote the conservation, protection, restoration, production, management and use of forestry resources in Mexico. The law also sets out the related jurisdictions for federal, state and municipal administrations. Furthermore, to foster sustainable forestry development, this law aims to:

- contribute to social, economic and environmental development, through integral sustainable management of forestry resources and other related ecosystems;

- encourage forestry activities which ensure better living conditions for producers and rural communities;

- develop environmental goods and services, and protect, maintain and increase forestry biodiversity;

- promote the organisation, operative capabilities and professionalization of public institutions responsible for fostering sustainable forestry development; and

- respect indigenous communities' acquired rights and usage preferences of forestry resources. 


\section{Rural Sustainable Development Law of 2001}

The Rural Sustainable Development Law, a regulatory law for Article 27 of the Constitution in matters pertaining to sustainable rural development, seeks to promote sustainable development in rural Mexico, facilitate the creation of adequate environmental conditions and ensure state control over the promotion of equitable development.

In the terms of this law, the concept of rural sustainable development includes the planning and organisation of agricultural production, as well as the means for its industrialisation and marketing. Activities directed towards rural sustainable development are carried out in conjunction with related activities that aim to improve rural welfare. In this sense, the law makes the state responsible for regulating and promoting such activities.

This law applies to all ejidos and rural communities, including their respective social organisations and associations. The law contains provisions designed to foster policies, actions and related programmes in rural communities, whilst adhering to its objectives, which are to:

- promote the social and economic welfare of rural communities, including producers and farmers, through diversification and generation of employment;

- achieve balance in rural development by providing differentiated attention to the least developed regions, whilst emphasising the promotion of productive and economic reconversion and transformation;

- contribute to food security in rural areas by encouraging agricultural production;

- foster biodiversity conservation and improvement in the quality of natural resources through their sustainable use; and

- assess the economic, environmental, social and cultural functions related to the agriculture sector.

\section{Ecological Equilibrium and Environmental Protection Law of 1987}

The general purpose of the Environmental Protection Law is to ensure the preservation and restoration of the country's ecological balance, as well as environmental protection throughout its territory, including areas subject to national jurisdiction and sovereignty.

The Environmental Protection Law also promotes sustainable development. It establishes basic rules to ensure the sustainable use, preservation and restoration of soil, water and other natural resources in such a way that activities to achieve economic benefits and social activities are compatible with environment preservation.

The law also sets out the jurisdictions of each level of government (federal, state, municipal). The federal government has jurisdiction over environmental impact assessments, and has the authority to authorise public works or other activities such as hydraulic and oil works, and petrochemical, chemical, steel, paper, sugar, cement and electricity industries (Appendix 1 - Social and Environmental Impacts). The federal government is also responsible for regulating the sustainable use, protection and preservation of national waters, biodiversity, fauna and all other natural resources within its jurisdiction and to issue laws regarding the sustainable use of energy resources.

The Environmental Protection Law sets out the requirements for Environmental Impact Assessments (EIAs). Under the relevant provisions, an EIA is mandatory for any land use change in tropical regions over an area of more than $20 \mathrm{ha}$, and any land use change in temperate regions over an area of more than $100 \mathrm{ha}$.

Article 28 of the Environmental Protection Law sets out the required procedure for EIAs. Under this provision, EIA is a procedure by which the Ministry of Environment oversees any activities that may cause environmental imbalance, in order to prevent or minimise any negative environmental impacts. Sections I and II of this article cover bioenergy facilities and activities, as the law considers all energy production activities and pipeline facilities to be environmental risk factors, regardless of their scope and size.

Details on how to obtain an EIA authorisation are given in Article 30. In short, interested parties must submit a detailed document that contains a description of their proposed project, an analysis of any negative risk factors that may affect the ecosystem, and preventive measures for mitigating or remedying the risk factors.

After the EIA is received by the Ministry of Environment, it is published in the Official Ecological Gazette for Public Consultations. However, a party that submits an EIA may classify or reserve information as deemed appropriate.

The ministry is required to make a decision on an EIA within 10 days of the required documentation being completed. The ministry can authorise the EIA, authorise the EIA subject to additional measures being undertaken on the proposed project or reject the EIA because (i) it violates relevant laws and regulations; (ii) it contains false information with regard to the environmental risks involved; or (iii) the proposed project may affect endangered species. 
Under the law, the commission is responsible for:

- elaborating short-, mid- and long-term programmes to promote biofuel production and commercialisation;

- $\quad$ executing coordination activities and agreements between the federal government, state and municipal authorities;

- following up and assessing existing or future programmes undertaken by the different implementing agencies, establishing performance indicators;

- fostering agro-industrial activities and infrastructure investment and best practices on the production and commercialisation of biofuel feedstocks;

- $\quad$ proposing policy and programmatic guidelines to be followed by the implementing agencies;

- conducting follow-up activities on the federal budget assigned to undertake biofuel promotion programmes and priority activities; and

- $\quad$ revising existing and proposed mandatory standards concerning biofuel production, commercialisation, transportation, distribution and efficient end-use.

However, in practice, there has been little compliance with these guidelines. For example, the state of Chiapas has issued an biofuel programme that includes subsidies for jatropha plantations, the establishment of 2 industrial plants and final use of biodiesel in public transport based on recycled cooking oil (in the cities of Tapachula and Tuxtla) - without any coordination by the Interministerial Commission on Bioenergy Development.

\subsubsection{Implementing agencies}

The Bioenergy Law sets out the entitlements and duties for the 3 federal implementing ministries energy, environment and agriculture - required to fulfil the law and carry out programmes and policies for biofuel promotion. Whilst each ministry has specific responsibilities and obligations, the law also sets out generic obligations, including the elaboration of specific policies and programmes, the application of mandatory standards and the elaboration of guidelines, requirements and criteria for the production, distribution, commercialisation and enduse of feedstock and biofuels.

\subsubsection{Biofuel promotional instruments}

The Bioenergy Law details the promotional instruments that implementing agencies must develop and apply in conjunction with state and local authorities, pursuant to their specific legal powers and responsibilities, in order to foster feedstock production and commercialisation, as well as the production, transport, distribution commercialisation and efficient use of biofuels.

The instruments must address feedstock production and biofuel production, as follows.

\section{Feedstock production}

- $\quad$ Foster productivity, competitiveness and employment creation;

- Consolidate the creation of rural companies, in which producers have a $30 \%$ interest;

- Quantify and determine the necessary incentives to foster feedstock production, by considering the performance of feedstock price and cost, exchange rates and the annual average investment rate of return; and

- Incentivise the diversified production of biofuel feedstocks.

\section{Biofuel production}

- Modernise biofuel production infrastructure, through the acquisition, purchase, installation and maintenance of biofuel production facilities; and

- $\quad$ Promote technology development aimed at reducing pollution emissions, as well as biofuel production innovation.

\subsubsection{Biofuels R\&D and training}

The agriculture and energy ministries are responsible for supporting and undertaking $\mathrm{R} \& \mathrm{D}$ and training programmes related to biofuel development, according to criteria developed by the ministerial biofuels commission. The law considers the following main activities:

- R\&D of sustainable feedstock production;

- biofuel production and distribution technologies;

- evaluation and feasibility procedures for biofuel production projects; and

- establishment of conditions for environmentally sound biofuel production. 
Table 1. Ministerial roles under the Bioenergy Law

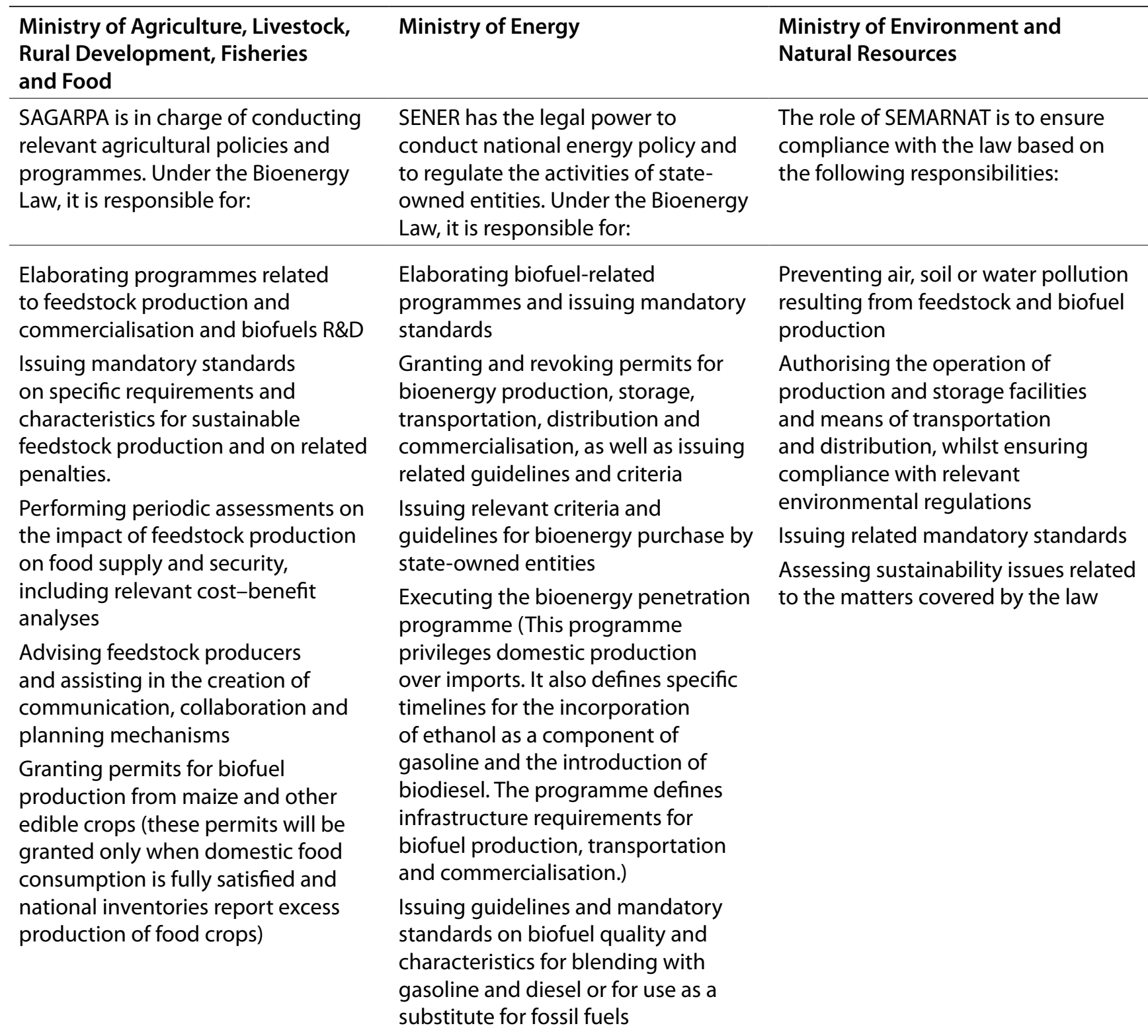

All biofuels R\&D and training activities are to be coordinated and supported by the National System on R\&D and Technology Transfer for Rural Sustainable Development. This body is also responsible for conducting related feedstock $\mathrm{R} \& \mathrm{D}$, providing technical advice on sustainable biofuel production, training human resources and developing and disseminating biofuel-related information.

This system is also responsible for developing a national programme on feedstock $R \& D$, which includes the participation of relevant $R \& D$ institutions, universities and producer organisations. It also assists in creating a national network of feedstock information and research.
The law provides for the federal government and its related agencies to develop other related $R \& D$ activities and support programmes.

\subsubsection{Procedures, permits and sanctions}

The Bioenergy Law stipulates that the Ministry of Energy (SENER), in conjunction with the Energy Regulatory Commission (CRE), will regulate all activities and services related to biofuel production, storage, transport, distribution and commercialisation, according to their legal competence. Such regulation will involve granting permits, establishing specific terms and conditions for the award, revocation and assignment of permits, ensuring compliance with related regulations and standards and imposing sanctions for violations. 


\subsubsection{Environmental Impact Assessment}

Under Article 13(II) of the Bioenergy Law, the Ministry of Environment and Natural Resources (SEMARNAT) is responsible for reviewing and, where applicable, authorising matters related to environmental impact, as well as facilities for the production, storage, transport, distribution and marketing of bioenergy feedstocks.

The Environmental Impact Assessment (EIA) of a project must receive authorisation from SEMARNAT before the project can receive the relevant permits from SENER or the CRE for the production, storage, transport, distribution or marketing of bioenergy.

It should be noted that neither the Bioenergy Law nor its applicable regulation contains any bioenergyspecific EIA procedures. Thus, the generic legal provisions contained in the Environmental Protection Law concerning EIA apply for bioenergy-related facilities and activities (see Box 2).

\subsubsection{Land use and restrictions}

Land use regulation in Mexico is complex, and it was thought that uncertainty concerning property and use rights could prove a major barrier to the development of the bioenergy industry. Therefore, to create greater legal certainty concerning land use and restrictions, the Bioenergy Law and its regulation set out legal provisions that are accounted for in the Rural Sustainable Development Law and other normative bodies.

In particular, Article 13(VI) of the Bioenergy Law grants SEMARNAT oversight of proper land use, to ensure that forestlands are not used for the production of crops for bioenergy production. In practice, however, enforcement is difficult because of the lack of supervision and a self-regulated scheme.

Articles 24, 50 and 55 of the Bioenergy Regulation set out the following rules.

Parties intending use agricultural crops to produce bioenergy feedstocks must submit a Sowing Notice (Aviso de Siembra) to the local offices of the agriculture ministry (a template is available on the ministry website). The notice must contain a statement made under oath that the bioenergy crops will be cultivated only on existing agricultural land and there will be no request to convert forestland into agricultural land.
For the purposes of monitoring land use, the Ministry of Agriculture, Livestock, Rural Development, Fisheries and Food (SAGARPA) will keep records of all Sowing Notices and permits granted. These records will be available to the Bioenergy Commission but not to the general public, pursuant to the federal Transparency Law.

Under Article 50, no feedstock cultivation undertaken within agricultural boundaries can trespass into forestland. All bioenergy-related agricultural activities must be undertaken under sustainability criteria, with due avoidance of land erosion and degradation.

The law also prohibits the cultivation of crops destined for feedstock production in areas with natural vegetation in which there exist endemic flora or animal species deemed endangered or under special protection, or in any other lands or spaces that are subject to special conservation measures under federal, state and/or municipal jurisdiction.

\subsubsection{Land acquisition and tenure}

Farmers may acquire land for large-scale operations subject to the restrictions set out in Article 27 of the Constitution. Under Article 27, private companies may acquire land for agricultural use, but 'certificates of non-affectability' (free from expropriation) cannot be granted for areas exceeding 100 ha under irrigation, 200 ha under seasonal cultivation or 300 ha under commercial crop cultivation.

Furthermore, land belonging to peasant (campesino) communities is under restrictions regarding acquisition and tenure. That is, ejidos (a form of individual campesino entitlement) can be acquired with the approval of the campesino assembly, but campesino land subject to collective ownership is inalienable and thus cannot be acquired.

State-owned land is inalienable if it is being used for public services and infrastructure. However, it can be sold to private parties following an administrative procedure of disincorporation. Otherwise, publicly owned land can be used by means of an administrative concession for the use or exploitation of such land.

Finally, farmers can acquire land for large-scale operations from other private parties by means of ordinary civil transactions such as sales, lease or any other types of contract. 


\section{Policy framework for biofuel promotion in Mexico}

The policy framework for biofuel promotion and development in Mexico is minimal and largely inchoate. An (unofficial) top-down representation of the Mexican policy framework related to bioenergy is depicted in Figure 2.

\subsection{Level I policies}

All policy instruments in Mexico should be aligned with the National Development Plan 2007-2012, which is the master document for all policies undertaken by the federal government in that period. The term of office for president in Mexico is 6 years; as such, incoming presidents design and publish their development plan at the beginning of their term. This system has serious implications for policy design and implementation and limits the development and execution of long-term plans.
The Special Climate Change Programme, also a Level I instrument, was created by the federal government and includes a number of actions to promote the use of biofuels in Mexico, in conjunction with related mitigation actions.

Mexico, which ratified the UNFCCC in 1993, has developed a National Climate Change Strategy, submitted 4 National Communications and created the Special Climate Change Programme. The programme was proposed as Mexico's Nationally Appropriate Mitigation Action and a plan for achieving voluntary mitigation goals when the country endorsed the Copenhagen Accord on 31 January 2010. An Interministerial Commission on Climate Change, established in 2005, acts as the Mexican Designated National Authority. The commission is supported by 5 working groups,

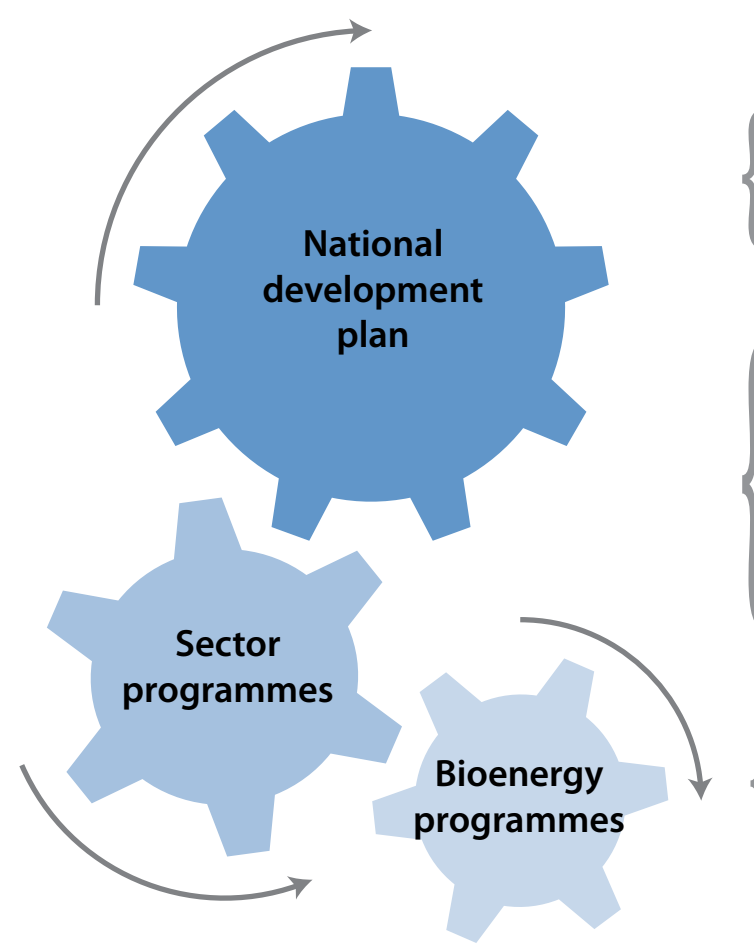

Level 1

1. National Development Plan (2007-2012)

2. Special Climate Change Programme (2009)

3. Interministerial Strategy for Bioenergy (2009)

Level 2

1. Energy Sector Programme (2007-2012)

2. National Strategy for Energy Transition (2009)

3. Special Programme for Sustainable Use of Energy (2010)

4. Environment and Natural Resources Sector Plan (2007-2012)

5. Agriculture and Livestock Sector Programme (2007-2012)

6. Mexico's Strategic Forestry Plan (2025)

7. National Forestry Commision - International Programme (2007-2012)

Figure 2. A representation of Mexico's bioenergy-related policy framework

Level 3

1. Bioenergy Penetration Programme (2010)

2. Sustainable Production of Feedstock for Bioenergy Programme (2008) 
including a Working Group on REDD coordinated by the National Forestry Commission (CONAFOR), and a permanent Advisory Council on Climate Change (C4).

Mexico received grant support in 2009 to develop a Readiness Preparation Proposal (R-PP) as a REDD Country Participant of the World Bank's Forest Carbon Partnership Facility (FCPF). CONAFOR developed the R-PP in consultation with the REDD Task Force and with input from El Colegio de la Frontera Sur (ECOSUR) and 19 civil society organisations. This process culminated in the creation of the REDD Working Group in November 2009. Mexico's REDD Strategy will be implemented at national, state (priority areas) and (local) property levels. CONAFOR is planning pilot REDD projects in El Ocote Ecological Reserve (Chiapas state)(with the National Commission for Natural Protected Areas (CONANP) and AMBIO Cooperative), the Lacandon Jungle (Chiapas state) and Los Tuxtlas Biosphere Reserve (Veracruz state). The state of Michoacán is planning a state-wide project. Furthermore, CONANP has identified potential project sites aimed at both reducing emissions and promoting adaptation to climate change impacts. Other federal structures are engaged in developing and implementing the national REDD Strategy. These include SAGARPA, National Commission for the Knowledge and Use of Biodiversity (CONABIO), SEMARNAT and the Federal Attorney for Environmental Protection (PROFEPA).

A third Level I instrument is the Interministerial Strategy for Bioenergy. The overall objective of this policy instrument is to foster feedstock production and commercialisation, as well as to promote biofuel production and end-use. This policy framework is also intended to ensure competitiveness and to open economic opportunities for the Mexican rural sector, particularly less developed communities, considering sustainability criteria that foster the introduction of biofuels in the energy mix of the transport sector.

The strategy objectives are given as follows:

- To foster the generation and exchange of information.

- To promote related $R \& D$ activities.

- To encourage related social and economic partnerships.
- To ensure market certainty.

- To encourage implementation, increased capability and biofuel production.

The first stage of the strategy programme addresses feedstock production and biofuel introduction. The strategy sets out plans to begin the production of approximately 3 million tonnes per year of sugarcane as feedstock to generate almost 200 million litres per year of ethanol. Plans state that in 2012 ethanol will be blended with gasoline for sale in the city of Guadalajara. The government's stated aim was that, by the end of the present federal administration, its related strategy and programmes would have achieved:

- sustainable production of multiple feedstocks for biofuel production;

- $\quad$ specific maps describing biofuel production potential;

- the establishment of a national programme for biofuel research and technology development;

- strengthening of the system-product chains which will contribute to feedstock and biofuel production;

- appropriate conditions to foster increased investment and employment creation in rural areas;

- contribution to increased reconversion and productive diversification of the primary sectors; and

- contribution to the preservation of natural resources and biodiversity, thus reducing greenhouse gas emissions.

A reform of the energy sector in 2008 introduced another Level I policy instrument, called the National Energy Strategy, which in certain aspects parallels the Energy Sector Programme. The National Energy Strategy is the first national programme to have a 15-year duration, as opposed to the 6-year presidential term. It is also the first policy instrument prepared by the executive branch that is subject to congressional approval. Although in relation to bioenergy it largely repeats the policy instruments mentioned above, it does emphasise the gradual incorporation of anhydride ethanol into gasoline in the main urban areas of Mexico. The strategy proposed the penetration of biodiesel in 2011, 
which would serve as a substitute for imported chemical additives.

\subsection{Level II policies}

The sector programmes of the various implementing agencies, such as SEMARNAT, SAGARPA and SENER, contain numerous references to specific policies and programmes. The most important policy instruments associated with the sustainable development of bioenergy are contained with the Energy Sector Programme 2007-2012.

The aim of the Energy Sector Programme is to ensure that the energy necessary for the development of the country is provided at competitive prices, whilst minimising any environmental impacts, operating under international quality standards and promoting the rational use of energy and diversification of primary sources. This is the first Energy Sector Programme to explicitly include the role of biofuels in the economy (previous programmes included nothing more than a brief mention of wood bioenergy).

Also relevant are environmental protection instruments, including forestry plans that form part of the Environment and Natural Resources Sector Plan 2007-2012, the Agriculture and Livestock Sector Programme and the National Forestry Commission - Institutional Programme. These programmes include provisions and text that appear also in the level I instrument, the Interministerial Strategy for Bioenergy, which indicates a clear intention to articulate all these within a single interministerial framework. However, these programmes, such as they are, have not yet evolved beyond their place on a list of goals. Specific and detailed programmes have not been either published or implemented. As such, most of the progress in the field of bioenergy policy is confined to a set of documents,. Land conservation gets one specific mention: the Agriculture and Livestock Sector Programme has set a target of conserving and improving 53 million ha by 2012 (but contains no explicit indication of which locations will be targeted).

The final instrument of relevance here, Mexico's Strategic Forestry Plan 2025, was published in 2000. Although this document was envisaged as a long-term development plan, it failed to identify the role of biofuels. Indeed, it contains no mention of the biofuels supply chain, with only a couple of paragraphs on the use of wood as a bioenergy feedstock.

\subsection{Level III policies}

The most important programmes related to bioenergy are the Sustainable Production of Feedstock for Bioenergy Programme (2008) and the Bioenergy Penetration Programme (2010).

The Sustainable Production of Feedstock for Bioenergy Programme (2008) was published by SAGARPA in accordance with the Interministerial Strategy for Bioenergy. The programme has a topdown structure that sets out its vision, mission, strategic actions and goals. The vision and mission statements are reproduced here.

Vision 2012

The chain of production and consumption of biofuels is competitive and profitable and it is an example of organisation and productive integration. Agricultural and energy economies have been integrated in order to determine the size of the industry, dominant conversion technologies and the crops that allow the best terms of use of resources, energy balance, economic and carbon emissions. Bioenergy is supplied to domestic markets according to quality requirements and there is enough capacity for exports. The integration of production chains and consumption of biofuels has led to rural sustainable development as well as highquality job creation. Bioenergy has also become a driver for technological development and research. The application of advanced technologies has enabled the country to overcome concerns related to food security, biodiversity, pollution, land use and water to be overcome.

\begin{abstract}
Mission
Actors who make up the chain of inputs, production and consumption of biofuels strive to improve the efficiency of material production and the conversion industry, expanding and developing technology markets. It is intended that biofuel offerings will adhere to sustainability criteria, and fulfil the highest quality requirements, and that their implementation in the national fuel mix will strengthen the nation's energy security, without affecting food security or disturbing the ecological balance. The bioenergy industry will create opportunities for the country's sustainable development.
\end{abstract}

The programme document identifies multiple feedstocks that SAGARPA considers promising: 
sugarcane, sweet sorghum and beet are earmarked for use for ethanol, whilst jatropha, castor and oil palm are earmarked as feedstocks for biodiesel production (Appendix 1). Areas of Mexico identified in the programme for feedstock production are shown on a map of the country in Figure 3.

Activities under the programme include the preparation of technical guidelines for cultivating the target feedstocks, along with socio-economic studies and proposals for future agricultural policies (Appendix 1). The programme also sets out a series of actions oriented towards supporting the introduction of these feedstocks, including technical and financial assistance. The programme contains no explicit provisions for avoiding deforestation, although occasional references indicate there is some awareness of the need to avoid deforestation and to promote the bioenergy supply chain from a sustainability perspective.

Two government institutions, SAGARPA and CONAFOR, have introduced specific financial incentives to promote biofuels. CONAFOR has created a grants programme that subsidises up to $70 \%$ of the establishment costs for jatropha plantations, as part of the ProÁrbol Programme. Under SAGARPA's Social Industrial Investment Projects, investors can apply for up to US\$6 million in grants, with total funding for 2011 amounting to US\$60 million (SAGARPA Programa de Bioenergéticos 2010).

Lists of the bioenergy feedstock projects in Mexico that were in the planning or implementation stages in early 2010 are presented in Tables 4 and 5. As the lists show, jatropha was seen as a preferred feedstock for new biodiesel projects. However, by early 2011, only a few biodiesel projects, and no ethanol projects, were actually operating. The only ethanol plant that has been built is that of DESTILMEX in Sinaloa state; however, it is not operating because the feedstock is corn, which Mexico does not allow as a legitimate biofuel feedstock for food security reasons.

Two main biodiesel projects are in operation. One is the Chiapas Bioenergético project, a government initiative, which involves the establishment of jatropha plantations in coordination with the National

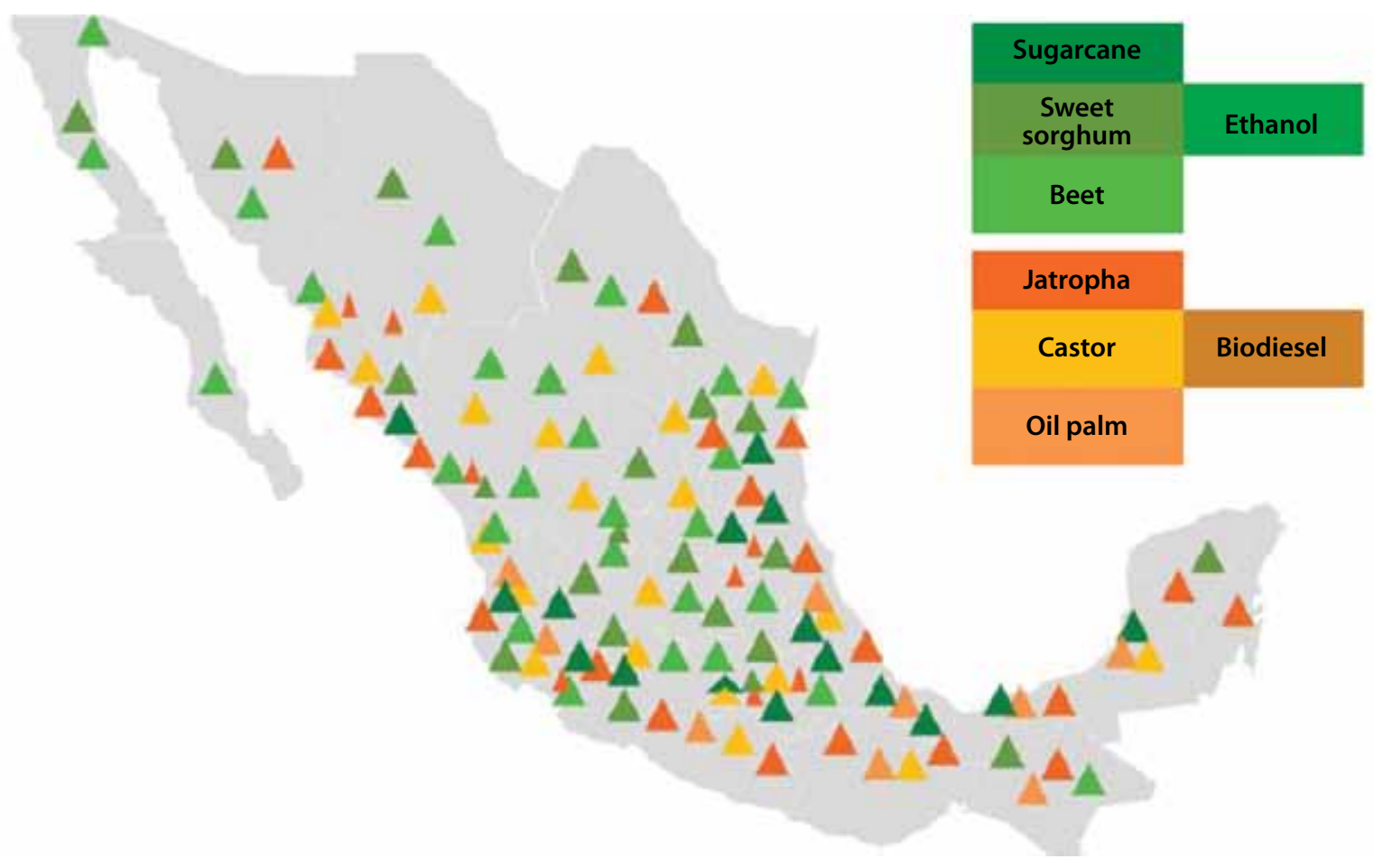

Figure 3. Map of areas targeted for cultivation of selected feedstocks for biofuels

Source: This image was adapted from Instituto Nacional de Investigaciones Forestales, Agricolas y Pecuarias (INIFAP), Mexico 
Forestry Commission (CONAFOR), which subsidises the establishment of the plantations, recycling of used cooking oil, 2 processing plants and an agreement with public transport authorities in 2 Mexican cities to use the biodiesel in buses. However, the president of Chiapas Bioenergético has indicated that the jatropha programme has slowed (Enrique R., personal communication 2011), as jatropha plantations have not been as successful as originally thought (i.e. producers have obtained substantially lower yields than expected). The second main project, located in Monterrey, involves the use of animal fat to produce biodiesel, which is later sold to PEMEX as lubricant.

In addition, several small projects are concentrating on establishing jatropha plantations, but the total area cultivated in Mexico is currently less than 5000 ha.
CONAFOR has been leading the National WoodEnergy Programme, launched in 2008, as part of its commitment to promote the sustainable use of forest resources for energy purposes. The aim of the programme is to increase the role of wood energy in the national energy supply. Strategies and lines of action include the sustainable use of fuels produced from forests and jungles. The programme includes plans to promote the use of rural-wood-saving stoves, whose objectives are:

- to reduce fuel consumption to mitigate the environmental impact on ecosystems caused by inadequate collection or use of wood for fuel;

- to reduce the risk of respiratory illness from smoke inhalation; and

- to contribute to improving rural incomes by reducing the costs of fuelwood collection or purchase.

Table 2. List of biodiesel feedstock projects

\begin{tabular}{|c|c|c|c|}
\hline $\begin{array}{l}\text { Location } \\
\text { (State) }\end{array}$ & Project & Feedstock & $\begin{array}{l}\text { Capacity } \\
\text { (million litres/ } \\
\text { year) }\end{array}$ \\
\hline \multicolumn{4}{|c|}{ Biodiesel } \\
\hline Chiapas & $\begin{array}{l}\text { 'Chiapas Bioenergético'. Supported by Chiapas state } \\
\text { government and the Bioenergy and Alternative Energy } \\
\text { Institute. Includes establishment of feedstocks, collection } \\
\text { of used cooking oil, } 2 \text { biodiesel plants. }{ }^{\text {a }} \text { The biodiesel is } \\
\text { used in } 100 \text { public transportation buses in the cities of } \\
\text { Tapachula and Tuxtla Gutiérrez. }\end{array}$ & $\begin{array}{l}\text { Currently based on } \\
\text { oil palm and used } \\
\text { cooking oil } \\
\text { Jatropha and castor }\end{array}$ & NA \\
\hline Monterrey & Biocombustibles Internacionales SA de CV & Used animal fat & 18 \\
\hline Colima & Supported by Colima state government & Jatropha & 17.5 \\
\hline Michoacan & Bioenermex de México SA de CV & Jatropha and castor & NA \\
\hline Michoacan & Jatro BioFuels & Jatropha & NA \\
\hline Morelos & PETRIUM SC & Jatropha & NA \\
\hline Oaxaca & Supported by Oaxaca state government & Jatropha & NA \\
\hline Puebla & Jose Luis Coutyolenc and Gabriel Hinojosa & $\begin{array}{l}\text { Pongamia and } \\
\text { jatropha }\end{array}$ & NA \\
\hline Sinaloa & $\begin{array}{l}\text { BioD Sinaloa, Biodiesel Industries SC, Delawer } \\
\text { Corporation }\end{array}$ & Jatropha & 12 \\
\hline Sonora & Seawater Foundation. & Salicornia bigelovii & 2.5 \\
\hline Yucatan & Grupo KUO (Kuosol SA de CV) & Jatropha & 200 \\
\hline Veracruz & Palmicultores del Campo SPR de RL & Oil palm & 150 \\
\hline NA & The Avery Group & Algae & 8176 \\
\hline
\end{tabular}

Source: IICA (2010) and Zamarripa (2009)

a Programmes currently in operation 
Table 3. List of bioethanol feedstock projects

\begin{tabular}{|c|c|c|c|}
\hline $\begin{array}{l}\text { Location } \\
\text { (State) }\end{array}$ & Project & Feedstock & $\begin{array}{l}\text { Capacity } \\
\text { (million } \\
\text { litres/year) }\end{array}$ \\
\hline Baja California & Supported by Baja California state government & Sorghum & NA \\
\hline Colima & Supported by Colima state government & Sugarcane & 54 \\
\hline Jalisco & Jorge Álvarez Zepeda & $\begin{array}{l}\text { Sugarcane and sweet } \\
\text { sorghum }\end{array}$ & 109 \\
\hline Morelos & $\begin{array}{l}\text { Compañía Morelense Agroindustrial y MAN Forestal de } \\
\text { México - Ing. Enrique Olvera }\end{array}$ & Sweet sorghum & 200 \\
\hline Morelos & CNC & Sugarcane & 50 \\
\hline Oaxaca & Supported by Oaxaca state government & Sugarcane & 43 \\
\hline Querétaro & BIOETAMEX (grupo COMEX) Alfredo Achar & $\begin{array}{l}\text { Sweet sorghum, } \\
\text { cellulose }\end{array}$ & 122 \\
\hline Sinaloa & DEXTILMEX SA de CV - Oscar Diarte & Corn & 110 \\
\hline Sinaloa & MEXSTARCH SA de CV - Ing Luis Ramon Lorence & Corn & 38 \\
\hline Sonora & $\begin{array}{l}\text { BIOFIELDS Energía Renovable y Sustentable - Eduardo } \\
\text { Gonzalez }\end{array}$ & Algae & 945 \\
\hline Tamaulipas & Supported by Tamaulipas state government & Sugarcane & 186 \\
\hline Tamaulipas & Supported by Tamaulipas state government & Sorghum & 190 \\
\hline Tamaulipas & Compañía Agroenergética Los Aztecas SA de CV & Sugarcane & 186 \\
\hline Veracruz & $\begin{array}{l}\text { BIOCOM SA Filial de Servicios Azucareros del Tropico SA de } \\
\text { CV - Jose Seoana Castro }\end{array}$ & Sugarcane & 14 \\
\hline NA & CITROTECNO SL & Citrics & NA \\
\hline NA & $\begin{array}{l}\text { Social producers and entrepreneur national network AC - } \\
\text { Rosanna Feruggi }\end{array}$ & Yucca & 0.2 \\
\hline NA & Empresas Santos & Sugarcane & 180 \\
\hline NA & Zajay de RL de CV & Coffee & 1.46 \\
\hline
\end{tabular}

Source: IICA (2010) and Zamarripa (2009)

None of the ethanol projects and plants listed in the table is currently operating to produce biofuels for transportation, and most of them have been put on hold.

To meet the programme objectives, CONAFOR provides support for the construction and installation of wood stoves. This forms part of its ProÁrbol Programme. Results for 2010 include the installation of 19683 approved stoves, at a value of MXN 28388766 (around US\$2.1 million).

The Bioenergy Penetration Programme, released in 2010, repeats much of the content of the Sustainable Feedstock Programme, along with some objectives related to the introduction of bioenergy. This is also a top-down document, with vision and mission statements similar to those in the Sustainable Production of Feedstock for Biofuels Programme.

The main purpose of the programme is to provide certainty in the development of an integrated biofuel supply chain, as an alternative to the current fuel mix, without jeopardising the food supply chain. The programme's specific objectives are: 
- to promote related $\mathrm{R} \& \mathrm{D}$ activities and adoption of clean technology;

- to diversify the energy mix to incorporate more renewable energy;

- to work closely with all sectors involved in the bioenergy supply chain;

- to generate new opportunities that foster agriculture and industry sectors, specifically cluster creation for small and medium enterprises; and

- to foster information exchange and quality, including new websites, and open access to government studies and databases.

The Bioenergy Penetration Programme includes a start-up plan in Mexico's central region (Guadalajara) to include ethanol as a gasoline oxygenate. It is estimated that $3400 \mathrm{bbl}$ of ethanol per day will be required to be mixed with the $48200 \mathrm{bbl}$ per day of gasoline used in the city. The investment required for this project is MXN 320 million in infrastructure (approx. US $\$ 28$ million) and a 2-year plan that includes preliminary studies, engineering, building and start-up of storage and mixing facilities (Appendix 1). The programme also recognises the dominant roles of production and transport costs in ethanol prices.

In terms of land use, the programme notes that 300000 ha will be used as feedstock land (Appendix 1). Planning for use of a large land area implies that companies need to sign contracts with independent landowners. As explained in section 2.4.9, the law does not permit large areas of land to be under single private ownership. Thus, some companies have adopted cooperative schemes with several - or many - private owners. The maximum permissible areas for agricultural lands are 50 and 200 ha (for seasonal or irrigated land, respectively). Finally, it should be pointed out that the programme contains no provision either for indirect land use change or for the impact of this plan in terms of deforestation. 


\section{The Mexican framework in the context of biofuel laws and regulations in Latin America}

This section presents a brief comparative analysis of the Mexican regulatory and policy framework in the context of the biofuel laws and regulations that have been approved and are being implemented in Argentina, Bolivia, Brazil, Colombia, Ecuador, Honduras, Paraguay and Peru. For a more complete discussion on this topic, see Masera et al. (2011).

The comparative analysis considers the following elements of the relevant laws:

- purpose and objectives;

- implementing agencies;

- policy framework for promotion and development, and market promotion;

- mandatory fuel requirements (blends and biofuel use); and

- elaboration and enforcement of additional rules or standards to complement the regulation.

It is important to note, however, that a few lessons can be learned from the effective implementation of biofuel laws in Latin America because, with the exception of Brazil, most such laws were enacted only recently (less than 3 years ago). In some cases, such as Mexico, the enforcement process mandates additional rules or programmes, which are not yet in force.

\subsection{Purpose and objectives of the regulations}

Each regulation's purpose clearly defines a specific approach on how to promote biofuel production and use, as well as a priority sector to be addressed in terms of its development - mainly the rural sector and most of these laws target national feedstock and biofuel production, thus promoting and prioritising national producers over importers. The promotional bases of most of these laws are consistent with social development strategies that are implemented in developed countries in which the participation of small and medium enterprises is fundamental.

Most of the regulations enacted and implemented with the aim of promoting biofuels are consistent with overarching policies to mitigate the effects of climate change and to ensure diversification of energy sources. This criterion also applies in terms of the numerous references contained within these laws with regard to environmental regulations and compliance with standards related to the preservation of natural resources, energy production and agricultural and industrial processes.

Most of the regulations have as their primary objectives the goals of reducing fossil fuel dependence and improving living standards for rural populations, by creating job opportunities and boosting incomes resulting from feedstock and biofuel production and end-use, without affecting food security.

\subsection{Implementing agencies}

The implementation and application of biofuel regulations include, in most cases, the participation of several implementing agencies which have specific responsibilities according to their attributes and operational functions. Energy ministries play a key role in implementing these regulations.

Follow-up activities and enforcement of other existing regulations and standards related to biofuel and feedstock production and promotion are covered by the relevant agriculture, environment, economy and treasury ministries. In the particular case of Mexico and countries such as Argentina, a governing body - a interministerial'commission on biofuel promotion and development - is established with the role of designing and integrating related biofuel promotion policies. 
Implementing attributes concerning biofuel regulations found in most cases cover the promotion, quality control and fiscal issues related to feedstock and production, as well as the elaboration and enforcement of further regulations and policies for the agriculture and industrial sectors.

Most biofuel regulations consider the establishment of promotional regimes for the biofuel production chain - with the exception of Mexico in which these elements have not yet been specifically defined. Some include subsidies for biofuel production to improve its competitiveness against fossil fuels.

\subsection{Policy framework for promotion and development, and market promotion}

Mexico's law mandates the elaboration and development of a specific policy and programmatic framework to promote feedstock and biofuel production. Similarly, other countries' regulations, particularly those of Peru, consider the definition of specific public policies.

Colombia's National Development Plan (2006-2010), includes a biofuels strategy. The regulation of ethanol use in gasoline blends, the promotion of production and commercialization of biodiesel to be used in diesel vehicles and policy guidelines to promote a sustainable production of biofuels (ethanol and biodiesel) are all aligned towards the biofuel strategy.

\subsection{Mandatory fuel requirements}

Argentina, Brazil and Mexico have published production targets for weight of feedstock or volume of fuel. Targets are meant to be part of a development plan to promote investment in the sector.

Some regulations include specific biofuel blending targets. The percentage and time span for complying with this requirement vary from country to country, ranging from $2 \%$ to $20 \%$ of biofuel participation, for periods of 3 to 20 years.

Mexico's biofuel law does not establish a specific requirement for biofuel blending with fossil fuels.
It only establishes a set of stages for the gradual introduction of biofuels.

Private investment targets are not specified in any of these biofuel policies although investment restrictions appear in Mexico.

Bioenergy is a form of production of fuels that is available for foreign direct investment, as opposed to gasoline and LPG gas, which are reserved for Mexican citizens. As such, private investors tend to look into feedstock production based on long-term leases or association with landowners.

From 2007 to 2010, many foreign private companies showed an interest in making substantial investments in biofuels in Mexico. However, due to the lack of definition in terms of blending targets for biodiesel, financial incentives to biodiesel and ethanol, biofuel prices, incentives to export, and other regulations, together with a less optimistic international panorama on biofuels, nearly all of these investors have cancelled the projects or put them on hold.

\subsection{Elaboration and enforcement of additional rules or standards}

Colombia and Argentina have invested additional efforts to establish a single promotion and supporting authority (e.g. a one-stop centre) through the creation of two commissions, the Intersectorial Commission for Biofuel Management and the Advisory National Commission for the Promotion of Biofuels Sustainable Production and Use.

Brazil has passed additional legal constraints to create disincentives for sugarcane expansion in the Amazon. It allows for no formal allocation of lands for biofuel production except on agricultural lands classified in the zoning plans.

Trade restrictions for genetically modified organisms (GMOs) are established in Mexico's Biosecurity and Genetically Modified Organisms Law (2005). This law regulates both the import and the export of GMOs in order to prevent, avoid and/or reduce the risks that such organisms could have on the environment, human, animal or vegetable health or on biological diversity. 
The Ministry of the Treasury oversees the import of GMOs in the following ways.

- At customs points in Mexican territory, it monitors GMOs to ensure they are permitted by authorities in their country of origin and that they are properly identified.

- Any GMOs that lack a proper permit or are not identifiable will not be allowed into the country.

- Mexican customs authorities will not allow into the country any GMOs that are forbidden in their country of origin or that are classified as forbidden in Mexican territory for commercial circulation.
Additional rules and other instruments are necessary to complement and to set out specific activities included in Mexico's biofuel-related laws. In this sense, the law mandates the elaboration of a rule which will provide all the details on feedstock and biofuel production and commercialisation guidelines, biofuel requirements, tax and fiscal incentives, procedures and plans for implementing agencies' responsibilities and legal powers. Other countries, including Ecuador and Honduras, are also considering the elaboration and enactment of specific rules to implement biofuel laws. 


\section{Discussion}

In recent years, Mexico has started to incorporate biofuels into both its legal framework and the national industrial sector, in order to achieve economic benefits and to create alternatives in a fossil-fuel energy-intensive economy. Mexico's heavy dependence on oil and other fossil fuels has been a major barrier to past attempts to promote biofuels. Nevertheless, recent energy and environmental policies (focused on providing a more diversified and less-polluting energy mix) have led to the creation of regulations to promote the use of biofuels.

Mexico has created laws, regulations and high-level programmes related to the promotion of bioenergy. However, the country lacks specific policies and a clear mix of incentives to translate the goals into concrete actions. For example, there are still no clear price incentives for local producers to make the production of biofuel feedstocks competitive with the current domestic gasoline and diesel prices.

Even the most recently published programmes are little more than a list of guidelines, structured under the logic of a business plan (vision, mission, objectives, actions). Mexico has already documented the 'what' questions, but documentation on the 'how' questions is not fully available.

Another issue requiring attention is the short-term nature of the programmes. For example, the 2012 Vision of the Bioenergy Penetration Programme is not founded on a realistic timetable. This may be related more to political than technical issues - as the presidential term is 6 years, public servants tend to plan programmes for the same time frame (in this case, 2007-2012). Therefore, the Programme envisages a fully and exemplarily integrated supply chain in 2012, which is unrealistic given the current situation.

According to the bioenergy penetration programme, most investment in biofuels will be private. However, the programme does not provide an estimate of the amount of investment needed, nor offer any finance mechanisms and/or incentives to attract investors.

Although the programmes indicate that R\&D will play a major role for biofuel development, there is little evidence supporting this ideal. The largest $\mathrm{R} \& \mathrm{D}$ funding available is through the CONACYTSENER sectorial funds, called the Sustainable Energy Programme and R\&D Energy, which are worth a total US\$35 million. In 2009, a call for proposals included one topic on bioenergy: 'ethanol from algae'. Seven research proposals were submitted in response to the call but none was accepted (Appendix 1). None of the money available in these funds has been given to biofuels R\&D (www.conacyt.mx).

Although all the official programmes state that biofuel plantations will not be established in native forests, the links between biofuel development and potential direct and indirect land use change have not been analysed in detail, and remain an area for policy development. The programmes contain no formal allocation of lands for biofuel production, but rather only recommended feedstocks according to agroecological zoning. There is no evidence that this will be enough to communicate and persuade some of the 30000 ejidos and private investors to undertake sustainable production of biofuel feedstocks.

Initiatives such as the Interministerial Strategy for Bioenergy indicate that future socio-economic and feasibility studies may support this task, although there is no express mention of specific projects and deadlines.

Attempts to promote the large-scale development of biofuels in Mexico whilst avoiding deforestation will require more attention to the agriculture and environment sectors - to date, bioenergy-related laws and policies are concentrated on the energy sector. Although official documents acknowledge the importance of promoting bioenergy as part of a sustainable development plan, the environment, forestry and agriculture sectors have 
no strong or clear provisions for mechanisms to avoid deforestation.

Two other issues that are important to contextualise in terms of the international debate on biofuels are their role in and impact on food security and energy security.

\subsection{Biofuels and food security}

Mexico's new legal framework for biofuels was issued in a context lacking a sound food security policy. In the process of the drafting and approval of the bioenergy law, no ex ante evaluations were made of commercial or agricultural activities related to food security. Moreover, Mexico has no social or official established networks specifically dealing with food security, apart from SAGARPA's network for monitoring the effect of biofuel production in the agricultural activities of vulnerable peasant groups in Mexico.

Although the recently approved biofuel legal and regulatory framework constitutes a step towards the development of an effective and sustainable biofuel industry in Mexico, the country has yet to introduce specific recommendations, as issued by international organisations. For instance, the Food and Agriculture Organization of the United Nations (FAO), in its High-Level Conference on World Food Security: The Challenges of Climate Change and Bioenergy, held in Rome in June 2008, issued the following recommendations, the adoption of which could enrich further legislative and regulatory amendments to Mexico's legal and institutional framework for bioenergy consumption and production:

- Evaluate the consequences of bioenergy expansion on food security.

- Create and measure a map of the impact of bioenergy development on food security.

- Move towards the creation of a methodology for the analysis of the life cycle of greenhouse gas emissions, whilst recognising the importance of emissions caused by direct and indirect changes in land use.

- Undertake accurate evaluation of the consequences of the expansion of bioenergy as a result in the change of land use.

- Supervise and map land use changes.
- Evaluate the cartography of marginal degraded land in order to evaluate its capacity to produce biomass.

Mexico lags behind other Latin American countries in terms of establishing a well-developed and stable biofuels market. As of 2011, no plant is operating to produce ethanol from biofuels to be used in the transport sector. Although PEMEX held 3 public bids to promote domestic production of ethanol, none was successful, mainly because of the low price offered for purchase of bioethanol. As for biodiesel, only 2 smallscale projects are operating, and the initial excitement about new feedstocks such as jatropha has waned.

Furthermore, a lot of work is required in terms of designing and implementing commercial and financial measures for the incipient biofuel industry. According to the State of Food and Agriculture report prepared by FAO in 2008, governments can undertake some of the following measures, amongst others:

- Avoid excessive regulatory burdens for producers that may result from a complex legal and institutional framework.

- Move towards the reduction of commercial obstacles for developing countries and smallscale producers and avoid the implementation of future obstacles.

- Avoid bioenergy and other subsidies as well as other types of state intervention that cause market distortions.

- Promote the harmonisation of import duties for biodiesel and bioethanol.

- Promote the use of financial funds provided by multilateral sources for sustainable production of biofuels.

- Promote and benefit from the financial mechanisms related to climate change mitigation, whilst widening the knowledge base and methodologies that are necessary to evaluate the benefits of bioenergy in reducing greenhouse gases.

\subsection{Biofuels and energy security}

In terms of energy security, and the role of bioenergy in the fuel mix in Mexico, several issues must be examined whilst revisiting the bioenergy institutional and legal framework. 
- Greater institutional coordination is necessary amongst the energy, environment and agriculture sectors to develop a congruent policy that includes biofuel as a significant element in Mexico's energy mix.

- Subsidies for fossil fuels such as diesel and gasoline create a major entry barrier for the production and consumption of biofuels in domestic markets.
- Another significant entry barrier is PEMEX, Mexico's national oil company, as the only supplier of gasoline and diesel in Mexico. Some producers may be discouraged from producing biofuels for domestic consumption if obliged to enter into a commercial relationship with PEMEX. 


\section{Conclusions}

Mexico is pursuing the production and consumption of bioenergy. The government has adopted an initial approach to devise the required policy instruments to foster the development of the bioenergy sector. As noted in this country report, Mexico is taking a top-down approach in its design of policy instruments, including coordination roles amongst state entities. These programmes include provisions and texts that appear also in the Interministerial Strategy for Bioenergy, which indicates a clear intention to articulate these provisions within a single interministerial framework. However, these programmes, such as they are, have not yet evolved beyond their place on a list of goals. Specific and detailed programmes have not been either published or implemented. As such, most of the progress in the field of bioenergy policy is confined to a set of documents, and exists on paper only.

Policy design to date contrasts sharply with the extent of projects actually implemented. Despite a long list of tentative projects published in 2010, several project plans have been put on hold, with little indication that they will be resumed soon. Incentives for bioenergy development have been hampered by multiple barriers such as problems in the verification of areas (not verified declared areas), survival feedstock percentages below the minimum and lack of a management plantation plan (new requirement to pay the subsidy).

Regarding efforts to avoid deforestation whilst promoting biofuels, the law stipulates that crops destined for feedstock production must not be cultivated in areas with natural vegetation in which there exist endemic flora or animal species deemed endangered or under special protection, or in any other lands or spaces which are subject to special conservation measures under federal, state and/or municipal jurisdiction. However, a statement contained within a policy is not enough to avoid deforestation. More needs to be done in the agriculture and environment sectors - to complement efforts in the energy sector - if the promotion of the large-scale development of biofuels in Mexico is to occur without deforestation. Clear provisions and mechanisms to avoid environmental damage, understand the impact of indirect land use and foster the role of the forestry and agriculture sectors in bioenergy development have yet to be put into practice. 


\section{References}

The following documents were consulted in the creation of this report.

\section{Mexican laws and regulations}

Constitución Política de los Estados Unidos Mexicanos, Articles 25 and 27, 1917.

Diario Oficial de la Federación, 28 January 1988. Ley General de Equilibrio Ecológico y la Protección al Medio Ambiente.

Diario Oficial de la Federación, 7 December 2001. Ley de Desarrollo Rural Sustentable.

Diario Oficial de la Federación, 25 February 2003. Ley General de Desarrollo Forestal Sustentable.

Diario Oficial de la Federación, 13 June 2003. Decreto por el que se reforma la Ley de Planeación publicada el 5 de enero de 1983.

Diario Oficial de la Federación, 26 December 2005. Decreto que reforma la Ley General de Desarrollo Forestal Sustentable.

Diario Oficial de la Federación, 2 February 2007. Decreto por el que se reforma la Ley de Desarrollo Rural Sustentable.

Diario Oficial de la Federación, 5 July 2007. Decreto por el que se reforma la Ley General de Equilibrio Ecológico y la Protección al Medio Ambiente.

Diario Oficial de la Federación, 1 February 2008. Ley de Promoción y Desarrollo de Bioenergéticos.

\section{Mexican bioenergy-related government programmes}

Comisión Intersecretarial sobre Cambio Climático 2008. Programa Especial sobre Cambio Climático.

Comisión Nacional Forestal 2001. Programa Estratégico Forestal para México 2025.

Comisión Nacional Forestal 2008. Programa Institucional 2007-2012.

Secretaría de Agricultura, Ganadería, Desarrollo Rural y Pesca 2008. Programa Sectorial de Agricultura, Ganadería, Desarrollo Rural y Pesca 2007-2012.

Secretaría de Agricultura, Ganadería, Desarrollo Rural y Pesca 2010. Programa de Producción Sustentable de Insumos para Bioenergéticos en México.
Secretaría de Energía 2008. Programa Sectorial de Energía 2007-2012.

Secretaría de Energía 2009. Estrategia Intersecretarial de los Bioenergéticos.

Secretaría de Energía 2009. Estrategia Nacional para la Transición Energética y el Aprovechamiento Sustentable de la Energía.

Secretaría de Energía 2010. Programa de Introducción de Bioenergéticos en México.

Secretaría de Medio Ambiente y Recursos Naturales 2008. Programa Sectorial de Medio Ambiente y Recursos Naturales 2007-2012.

\section{Other sources}

Charles, M.B., Ryan, R., Ryan, N. and Oloruntoba, R. 2007 Public policy and biofuels: the way forward? Energy Policy 35: 5737-5746.

Enrique, R. Red Mexicana de Bioenergía (Rembio). Personal communication 2010.

Instituto Interamericano de Cooperación para la Agricultura (IICA) 2010 Atlas de la agroenergía y los biocombustibles en las Américas: II Biodiesel. IICA, San José, Costa Rica.

Masera, O., Prehn, M., Pacheco, P., Schoneveld, G. and Yen, L. 2010 Report for activity 4.1 project: Bioenergy, sustainability and trade-offs: can we avoid deforestation while promoting bioenergy? Biofuel development in Latin America: a review of main trends. March 2010.

Segura, S. 2008 Biotop biofuels assessment on technical opportunities and research needs for Latin America. Mapping of the biofuel sector in Latin America - Work Package 2. Report on biofuel policies and regulations in Mexico. Prepared by Sergio A. Segura for UNAM. July 2008.

Zamarripa, A. 2009 Coordinador Nacional de la Red de Investigación e Innovación en Bioenergéticos. Situación actual de los biocombustibles en México. Paper presented at the Primera Reunión de la Red Mesoamericana de Investigación y Desarrollo en Biocombustibles. Tuxtla Gutiérrez, Chiapas, Mexico, 10 August. 


\section{Appendix 1. Framework for analysis (based on Masera et al. 2010)}

\begin{tabular}{|c|c|c|}
\hline Parameter & Variable & Mexico \\
\hline $\begin{array}{l}\text { Nature and } \\
\text { status of } \\
\text { strategy }\end{array}$ & $\begin{array}{l}\text { What form does the strategy take } \\
\text { and when was it approved? }\end{array}$ & $\begin{array}{l}\text { Interministerial Strategy for Bioenergy (2009-2012), Bioenergy } \\
\text { Penetration Programme, Sustainable Production of Feedstock for } \\
\text { Bioenergy Programme }\end{array}$ \\
\hline \multirow{21}{*}{$\begin{array}{l}\text { Industry/ } \\
\text { investment } \\
\text { promotion }\end{array}$} & Promotion of specific feedstock & Bioethanol: Sugarcane, sugar beet, sweet sorghum \\
\hline & & Biodiesel: Jatropha, palm oil, castor bean \\
\hline & \multirow{3}{*}{$\begin{array}{l}\text { Production targets (volume } \\
\text { or weight of processed or } \\
\text { unprocessed product) }\end{array}$} & $\begin{array}{l}\text { 2011: For the Metropolitan Zone of Guadalajara: } 176 \text { million litres/year } \\
\text { (ethanol) }\end{array}$ \\
\hline & & $\begin{array}{l}\text { 2012: For the Metropolitan Zones of Guadalajara, Monterrey and Mexico } \\
\text { Valley: } 810 \text { million litres/year (ethanol) }\end{array}$ \\
\hline & & $\begin{array}{l}\text { Biodiesel: No targets established, only support for biodiesel (jatropha) } \\
\text { plants established }\end{array}$ \\
\hline & \multirow[t]{3}{*}{ Expansion targets (ha/time) } & Requested area to achieve production targets: \\
\hline & & 2011: 23467 ha (ethanol) \\
\hline & & 2012: 108000 ha (ethanol) \\
\hline & $\begin{array}{l}\text { Private investment targets } \\
(\$ / \text { time, in what field })\end{array}$ & $\begin{array}{l}\text { The Bioenergy Penetration Programme states that most investment will be } \\
\text { private but does not include a specific amount. }\end{array}$ \\
\hline & $\begin{array}{l}\text { Investment commitments by } \\
\text { government }(\$, \text { in what field } 1)\end{array}$ & $\begin{array}{l}\text { For the first stage (Guadalajara 2011): around US\$16.5 million for } \\
\text { infrastructure; 2012: around US\$10 million in Monterrey; around US\$40.7 } \\
\text { million in Mexico Valley }\end{array}$ \\
\hline & $\begin{array}{l}\text { Nature of public investments in } \\
\text { R\&D (if any) }\end{array}$ & $\begin{array}{l}\text { The largest R\&D funding available is through the CONACYT-SENER sectorial } \\
\text { 'Sustainable Energy Programme' and 'R\&D Energy' programmes. Seven } \\
\text { research proposals were submitted in responses to the 'ethanol from algae' } \\
\text { project but none was accepted. The } 2 \text { funds total MXN } 350 \text { million, but } \\
\text { none of that money has been given to biofuels-related R\&D } \\
\text { (www.conacyt.mx). }\end{array}$ \\
\hline & Import tariffs on fuel & Not specified in biofuel policy \\
\hline & $\begin{array}{l}\text { Exemption of import tariffs on } \\
\text { biofuels } 2\end{array}$ & Not specified in biofuel policy \\
\hline & $\begin{array}{l}\text { Reduced import levies on } \\
\text { capital goods }\end{array}$ & $\begin{array}{l}\text { A new document was published in August 2009: Policy and metrics to } \\
\text { promote the integration of national renewable energy equipment, which } \\
\text { includes a section for bioenergy and reduce levies on capital goods } \\
\text { (SENER 2009) }\end{array}$ \\
\hline & $\begin{array}{l}\text { Tax incentives (\% reductions on } \\
\text { value added, corporate income, } \\
\text { capital transfer, property tax) }\end{array}$ & Not specified in biofuel policy \\
\hline & Preferential/subsidised loans & Not specified in biofuel policy \\
\hline & Subsidies & $\begin{array}{l}\text { Not specified in biofuel policy. However, there are indirect subsidies in } \\
\text { agro-industry for the following: water, diesel, fixed price for some crops. }\end{array}$ \\
\hline & $\begin{array}{l}\text { Single promotion and supporting } \\
\text { authority (e.g. one-stop centre) }\end{array}$ & $\begin{array}{l}\text { Creation of the Interministerial Commission for Bioenergy Development } \\
\text { (Ministry of Energy, Ministry of Agriculture, Livestock, Rural Development, } \\
\text { Fishing and Food, Ministry of Environment and Natural Resources, Ministry } \\
\text { of Economy and Ministry of Treasury and Public Credit). This commission is } \\
\text { only in charge of designing the policies. It does not regulate or enforce. }\end{array}$ \\
\hline & Guaranteed off-take & Not specified in biofuel policy \\
\hline & Guaranteed prices & Not specified in biofuel policy \\
\hline & $\begin{array}{l}\text { Provisions for policy } \\
\text { implementation }\end{array}$ & Not specified in biofuel policy \\
\hline
\end{tabular}




\begin{tabular}{|c|c|c|}
\hline Parameter & Variable & Mexico \\
\hline \multirow{11}{*}{$\begin{array}{l}\text { Provisions } \\
\text { to enhance } \\
\text { benefits capture } \\
\text { from FDI }\end{array}$} & $\begin{array}{l}\text { Co-benefits (knowledge transfer, } \\
\text { employment quotas) }\end{array}$ & Not specified in biofuel policy \\
\hline & $\begin{array}{l}\text { Taxes (value added, corporate } \\
\text { income, capital transfer, } \\
\text { property tax) }\end{array}$ & Not specified in biofuel policy \\
\hline & $\begin{array}{l}\text { Fiscal decentralisation } \\
\text { (Yes } / \text { No, } \% \text { retrocession of taxes } \\
\text { and royalties, to whom) }\end{array}$ & Not specified in biofuel policy \\
\hline & $\begin{array}{l}\text { Domestic distribution quotas } \\
\text { (\% fuel to be sold domestically) }\end{array}$ & Not specified in biofuel policy \\
\hline & $\begin{array}{l}\text { Royalties (\% profit paid } \\
\text { to government) }\end{array}$ & Not specified in biofuel policy \\
\hline & $\begin{array}{l}\text { Joint venture provisions (\% } \\
\text { national ownership) }\end{array}$ & Not specified in biofuel policy \\
\hline & Restrictions on capital flight & Not specified in biofuel policy \\
\hline & Minimum levels of reinvestment & Not specified in biofuel policy \\
\hline & $\begin{array}{l}\text { Domestic processing } \\
\text { requirements }\end{array}$ & Not specified in biofuel policy \\
\hline & Value capture in rural areas & Not specified in biofuel policy \\
\hline & $\begin{array}{l}\text { Provisions to monitor } \\
\text { mechanisms for FDI benefits } \\
\text { capture }\end{array}$ & Not specified in biofuel policy \\
\hline \multirow[t]{8}{*}{$\begin{array}{l}\text { Domestic } \\
\text { consumption }\end{array}$} & $\begin{array}{l}\text { Blending targets } \\
(\mathrm{Y} / \mathrm{N}, \% \text {, timeframe })\end{array}$ & $\begin{array}{l}\text { Ethanol: 2\%, } 2011 \text { in Guadalajara Metropolitan Zone; } 2012 \text { also in } \\
\text { Monterrey and Mexico Valley Metropolitan Zones }\end{array}$ \\
\hline & Mandatory or voluntary blending & Mandatory \\
\hline & Quality standards & Not specified in biofuel policy \\
\hline & Subsidised cooking stoves & $\begin{array}{l}\text { There is a national programme to install } 500000 \text { improved stoves in the } \\
100 \text { poorest municipalities by } 2012 \text {. }\end{array}$ \\
\hline & $\begin{array}{l}\text { Subsidy to reduce price for } \\
\text { consumers }\end{array}$ & Not specified in biofuel policy \\
\hline & Export duties on raw product & Not specified in biofuel policy \\
\hline & $\begin{array}{l}\text { Export duties on processed } \\
\text { biofuels }\end{array}$ & Not specified in biofuel policy \\
\hline & $\begin{array}{l}\text { Import/promotion of } \\
\text { flexfuel motors }\end{array}$ & Not specified in biofuel policy \\
\hline $\begin{array}{l}\text { Promotion of } \\
\text { market-based } \\
\text { instruments }\end{array}$ & $\begin{array}{l}\text { Commitments to certification } \\
\text { standard (e.g. RSB, RSPO, EU, RSS) }\end{array}$ & Not specified in biofuel policy \\
\hline
\end{tabular}




\begin{tabular}{|c|c|c|}
\hline Parameter & Variable & Mexico \\
\hline \multirow[t]{6}{*}{ Land allocation } & $\begin{array}{l}\text { Development-induced } \\
\text { displacement permitted }\end{array}$ & Not specified in biofuel policy \\
\hline & $\begin{array}{l}\text { Land can be acquired through } \\
\text { conveyance } 3\end{array}$ & Not specified in biofuel policy \\
\hline & $\begin{array}{l}\text { Area of land designated for } \\
\text { concessions (ha) }\end{array}$ & Not specified in biofuel policy \\
\hline & $\begin{array}{l}\text { Criteria for prioritising } \\
\text { areas targeted (economic, } \\
\text { environmental, other) }\end{array}$ & $\begin{array}{l}\text { Not specified in biofuel policy. In terms of land conservation, the } \\
\text { Agriculture and Livestock Sector Programme indicates that } 53 \text { million ha } \\
\text { will receive some kind of help in order to rehabilitate and improve the } \\
\text { condition of the land used for agronomy purposes. }\end{array}$ \\
\hline & $\begin{array}{l}\text { Land use constraints (restrictions } \\
\text { to expansion in certain areas, } \\
\text { zoning policies) }\end{array}$ & $\begin{array}{l}\text { Not specified in biofuel policy. Some land extensions are protected areas } \\
\text { covered by the Natural Protected Areas Law. }\end{array}$ \\
\hline & $\begin{array}{l}\text { Who makes land allocation } \\
\text { decisions (sector, level) }\end{array}$ & Not specified in biofuel policy \\
\hline \multirow[t]{12}{*}{$\begin{array}{l}\text { Social and } \\
\text { environmental } \\
\text { impacts }\end{array}$} & $\begin{array}{l}\text { Intention to apply (develop and/ } \\
\text { or adopt) sustainability standards }\end{array}$ & $\begin{array}{l}\text { - Use of sustainability criteria in biomass production for ethanol (water, air, } \\
\text { biodiversity and soil) } \\
\text { - Contribution to the issuance of Mexican Official Norms related to } \\
\text { sustainable feedstock production }\end{array}$ \\
\hline & $\begin{array}{l}\text { Type of land designated for } \\
\text { biofuels (forest/woodland, } \\
\text { degraded, agriculture, peatland) }\end{array}$ & $\begin{array}{l}\text { The Agriculture and Livestock Sector Programme set a goal of } 300000 \text { ha } \\
\text { of land used for biofuel purposes by 2012, without specifying the type } \\
\text { of land. }\end{array}$ \\
\hline & $\begin{array}{l}\text { ElA required }(\mathrm{Y} / \mathrm{N} \text {, at what scale of } \\
\text { investment } 4\end{array}$ & $\begin{array}{l}\text { Not specified in biofuel policy. However, the Ecological Equilibrium and } \\
\text { Environmental Protection Law, Art. 3, indicates that EIA is compulsory for } \\
\text { all changes of land use and for forest plantations. }\end{array}$ \\
\hline & $\begin{array}{l}\text { Feasibility studies to guide } \\
\text { feedstock promotion? ( } \mathrm{Y} / \mathrm{N}, \\
\text { choice of feedstock and rationale) }\end{array}$ & $\begin{array}{l}\text { The National Institute on Agriculture and Forestry Research (INIFAP) has } \\
\text { established experimental plots in different parts of the country, and is } \\
\text { conducting feasibility studies on selected feedstocks (jatropha, castor, } \\
\text { sugar beet, sweet sorghum and others) }\end{array}$ \\
\hline & $\begin{array}{l}\text { Provisions for reducing impact on } \\
\text { food security }\end{array}$ & $\begin{array}{l}\text { There are provisions in the biofuels laws - food security must always } \\
\text { be assured before biofuel production. This is a priority statement in } \\
\text { bioenergy programmes. However, there are no details on enforcing this at } \\
\text { a local level. }\end{array}$ \\
\hline & $\begin{array}{l}\text { Provisions for avoiding } \\
\text { deforestation (e.g. in EIAs, EMP, } \\
\text { land policies) }\end{array}$ & Not specified in biofuel policy \\
\hline & $\begin{array}{l}\text { Specifications for waste } \\
\text { processing/removal }\end{array}$ & Not specified in biofuel policy \\
\hline & $\begin{array}{l}\text { Specifications for regulating } \\
\text { water use, avoiding / mitigating } \\
\text { water contamination }\end{array}$ & Not specified in biofuel policy \\
\hline & Use of by-products & Not specified in biofuel policy \\
\hline & Regulations on seeds & Not specified in biofuel policy \\
\hline & $\begin{array}{l}\text { Proportion of land set aside for } \\
\text { food crops }\end{array}$ & $\begin{array}{l}\text { As previously indicated, there are provision in the biofuels laws - food } \\
\text { security must always be assured before biofuel production. }\end{array}$ \\
\hline & $\begin{array}{l}\text { Preference to marginalised } \\
\text { groups }\end{array}$ & Not specified in biofuel policy \\
\hline
\end{tabular}




\begin{tabular}{|c|c|c|}
\hline Parameter & Variable & Mexico \\
\hline \multirow[t]{6}{*}{$\begin{array}{l}\text { Smallholder } \\
\text { Production }\end{array}$} & $\begin{array}{l}\text { Preferential/subsidised loans } \\
\text { targeting smallholders }\end{array}$ & $\begin{array}{l}\text { The Ministry of Agriculture will support: seed and vegetative material } \\
\text { reproduction, development of production projects, mechanisation, } \\
\text { technification of irrigation, pilot projects, financial support for biomass } \\
\text { production projects }\end{array}$ \\
\hline & $\begin{array}{l}\text { Government-supported training } \\
\text { and extension for biofuels }\end{array}$ & Training and technical guidance \\
\hline & $\begin{array}{l}\text { Local sourcing requirements } \\
\text { (inputs) }\end{array}$ & Not specified in biofuel policy \\
\hline & $\begin{array}{l}\text { Local sourcing requirements } \\
\text { (feedstock) }\end{array}$ & Not specified in biofuel policy \\
\hline & $\begin{array}{l}\text { Instruments to promote collective } \\
\text { efficiency (horizontal linkages } \\
\text { amongst producers) }\end{array}$ & Not specified in biofuel policy \\
\hline & $\begin{array}{l}\text { Extent to which subnational } \\
\text { governments and other actors } \\
\text { are involved in defining and } \\
\text { financing the above }\end{array}$ & Not specified in biofuel policy \\
\hline
\end{tabular}




Mexico has recently taken significant steps toward promoting the bioenergy sector. Motivations to adopt bioenergy include: energy security, economic development and international commitments to reduce greenhouse gas emissions. These opportunities also raise concerns including the influence that expanding biofuel production may have on deforestation rates. Well-guided policies may help address this concern.

This country report includes an analysis of the legal and institutional frameworks that underpin Mexico's bioenergy sector, including provisions of policies, laws and regulations.

The Mexican legal framework is well defined. The policy framework is a top-down structure with national plans at the top, linked to several sector and ministerial plans, which are finally linked to specific programmes. These programmes include strategies and subprogrammes that need to be developed in order to target feedstock, production, trade and sustainability objectives. Only a few sets of laws specifically address biofuels, and these focus on activities in the energy sector and disregard the implications for potential deforestation. Mexico has already documented priority tasks and goals, but documentation on programme details or in-depth analysis of plans, beyond simple statements, are still not fully available. Further efforts are required in the effects in agriculture and to the environment if we seek to avoid deforestation while promoting large-scale development of biofuels in Mexico. Clear provisions and integrated mechanisms that avoid environmental damage and foster the role of forestry and agriculture sectors on bioenergy have yet to be put in practice.

\section{ITEIII} policies and practices that affect forests in developing countries. CIFOR is one of 15 centres within the Consultative Group on International Agricultural Research (CGIAR). CIFOR's headquarters are in Bogor, Indonesia. It also has offices in Asia, Africa and South America. 